\title{
ANALISIS PENGUNJUNG PASIEN RAWAT JALAN DI RUMAH SAKIT DUSTIRA PRE AND POST SEBAGAI RUMAH SAKIT RUJUKAN COVID-19
}

\author{
Dina Nur Haliza ${ }^{1}$, Dina Sonia ${ }^{2}$ \\ Politeknik Piksi Ganesha Bandung ${ }^{1,2}$ \\ Dinanurhaliza0003@gmai.com ${ }^{1}$; nasoniaonya.ds@gmail.com²
}

Received: 29-07-2021

Revised : 17-11-2021

Accepted: 18-11-2021

\begin{abstract}
Abstrak
Latar Belakang: Pada Desember 2019 lalu, di kota Wuhan, Tiongkok, telah terjadi peristiwa luar biasa atas kasus radang paru-paru atau dalam istilah medis disebut Pneumonia yang di sebabkan oleh virus yang belum pernah dikenal sebelumnya, yang kini virus itu dikenal Novelcorona Virus. Sementara itu, Rumah Sakit Dustira yang menjadi salah satu Rumah Sakit rujukan COVID-19. Berdasarkan penelitian banyaknya pasien COVID-19 yang dirujuk ke Rumah Sakit Dustira sehingga jumlah pengunjung pasien rawat jalan di Rumah Sakit Dustira setelah menjadi Rumah Sakit rujukan COVID-19 sangat menurun.
\end{abstract}

Tujuan: Penelitian ini bertujuan untuk menjelaskan atau mendeskripsikan apakah ada hubungannya jumlah pengunjung pasien rawat jalan di Rumah Sakit Dustira setelah Rumah Sakit Dustira menjadi Rumah Sakit rujukan COVID-19.

Metode: Penulis menggunakan metode penelitian kuntitatif dalam proses penelitian dan dengan pendekatan deskriptif. Penulis menggunakan teknik pengumpulan data dengan sumber data primer dan data sekunder.

Hasil: Hasil penelitian grafik menunjukan adanya penurunan pada pengunjung pasien rawat jalan sudah terjadi dari tahun 2018 dimana jumlah pengunjung ada 349.117, tahun 2019 295.680, dan tahun 2020118.307 pasien, bukan karena Rumah Sakit Dustira sebagai Rumah Sakit rujukan COVID19. Dari hasil wawancara penulis menemukan jawaban bahwa kebijakan sistem regional yang ditetapkan oleh BPJS lah yang menjadi alasan Rumah Sakit Dustira mengalami penurunan jumlah Pengunjung pasien rawat jalan.

Kesimpulan: Kesimpulan penelitian ini adalah sebagai Rumah Sakit rujukan COVID-19 tidak menjadikan Rumah Sakit Dustira mengalami penurunan jumlah pengunjung pasien rawat jalan, dalam sesi wawancara penulis menemukan jawaban bahwa kebijakan sistem regional yang ditetapkan oleh BPJS lah yang menjadi alasan Rumah Sakit Dustira mengalami penurunan jumlah pengunjung pasien rawat jalan, Rumas Sakit Dustira sebagai Rumah Sakit rujukan COVID-19 tidak memberi pengaruh terhadap 
jumlah pengunjung pasien rawat jalan berarti untu $\mathrm{H} 0$ diterima dan $\mathrm{H} 1$ ditolak

Kata kunci: rekam medis; rumah sakit rujukan; COVID-19; pengunjung rawat jalan.

\begin{abstract}
Background: Last December 2019, in the city of Wuhan, China, there was an extraordinary event of pneumonia caused by a virus from a large family of corona viruses, but this virus has never been known before, so it is called corona. new type or Novel Corona Coronavirus. Dustira Hospital is one of the COVID-19 referral hospitals. Based on research, the number of COVID-19 patients who were referred to Dustira Hospital so that the number of outpatient visitors at Dustira Hospital after becoming a COVID-19 referral hospital greatly decreased.
\end{abstract}

Objective: This study aims to explain or describe whether there is a relationship between the number of outpatient visitors at Dustira Hospital after Dustira Hospital became a COVID-19 referral hospital.

Methods: The author uses a quantitative research method in the research process and with a descriptive approach. The author uses data collection techniques with primary data sources and secondary data.Results: The results of the graphic study show that a decrease in outpatient visitors has occurred since 2018 where there were 349,117 visitors, in 2019 295.680, and in 2020 118.307, not because of Dustira Hospital as a COVID-19 referral hospital. From the results of the interview, the author found the answer that the regional system policy set by BPJS was the reason Dustira Hospital experienced a decrease in the number of outpatient visitors.

Conclusion: The conclusion of this study is that as a COVID-19 referral hospital, Dustira Hospital does not experience a decrease in the number of outpatient visitors, in the interview session the author found the answer that the regional system policy set by BPJS was the reason Dustira Hospital experienced a decrease in the number of patients. outpatient visitors, Dustira Hospital as a referral hospital for COVID-19 has no effect on the number of outpatient visitors, it means that $\mathrm{HO}$ is accepted and $\mathrm{HI}$ is rejected Keywords: medical record; referral hospital; COVID-19; outpatient visitors.

*Correspondent Author: Dina Nur Haliza Email: Dinanurhaliza0003@gmai.com

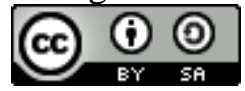

\title{
PENDAHULUAN
}

Era postmodern ini, sejarah kembali berulang, hampir dapat dipastikan seluruh Negara di dunia digemparkan oleh penyakit menular dengan jenis penyakit pneumonia Analisis Pengunjung Pasien Rawat Jalan di Rumah Sakit Dustira Pre and Post Sebagai Rumah Sakit Rujukan COVID-19 
(Lukman \& Malik, 2020). Penyakit ini pertama kali muncul di pasar hewan kota Wuhan provinsi Hubei Tiongkok yang dilaporkan oleh WHO China country office pada 31 Desember 2009 yang lalu (Oktaviani, 2021).

Tidak hanya di Tiongkok ditemukan pula sebanyak 98 kasus yang terjadi di luar Tiongkok yang tersebat di 18 negara. Singkatnya, berangkat dari situasi tersebut, WHO pada tanggal 30 Januari 2020 menetapkan virus penyebab pneumonia yang muncul di Wuhan-Tiongkok sebagai Public Health Emergency of International Concern (PHEIC)/Kedaruratan Kesehatan Masyarakat yang Meresahkan Dunia (KKMMD) dan kemudian pada tanggal 12 Februari 2020, WHO (World Health Organization) secara resmi mengumumkan penamaan baru virus penyebab pneumonia yang menyebar secara cepat itu dengan nama Severe Acute Respiratory Syndrome Coronavirus-2 (SARS-CoV-2) dan nama penyakitnya adalah Coronavirus Disease 2019 (COVID-19) (Nabila, 2021).

Indonesia sempat menempati peringkat ke-2 Negara terbanyak di Asia Tenggara setelah Singapura dan sebelum Filipina (Wulandari, 2021). Riwayat angka kematian, Indonesia pernah tercatat di peringkat ke-5 terbanyak di Asia. Namun, angka kematian diperkirakan jauh lebih tinggi dari data yang dilaporkan, lantaran tidak dihitung kasus kematian dengan gejala COVID-19 akut yang belum di konfirmasi atau di tes (Megakartikaningtyas, 2021). Bahkan, Direktur Jenderal Organisasi Kesehatan Dunia (WHO) Tedros Adhanom Ghebreyesus mengirim surat kepada Presiden Joko Widodo pada 10 Maret 2020, agar Indonesia lebih serius dalam menangani pandemic COVID-19 (Launa, 2020).

Pemerintah Indonesia lalu menyiapkan Rumah Sakit rujukan infeksi virus corona di 34 provinsi. Penetapan Rumah Sakit tersebut berdasarkan keputusan Menteri Kesehatan RI Nomor HK.01.07/MENKES/169/2020 tentang penetapan Rumah Sakit rujukan penanggulangan penyakit infeksi Emerging tertentu. Di mana pada menetapkan bagian ke satu bahwa menetapkan rumah sakit rujukan penanggulangan penyakit infeksi emerging tertentu sebagimana tercantum dalam lampiran yang merupakan bagian tidak terpisahkan dari keputusan menteri ini ( $\underline{\mathrm{HK}}, 2020)$. Salah satu dari list rumah sakit tersebut adalah RumKit TK II 03.05.01 Dustira.

Sesuai dalam undang-undang nomor 44 tahun 2009 tentang Rumah Sakit bahwa rumah sakit adalah institusi pelayanan kesehatan yang menyelenggarakan pelayanan kesehatan perorangan serta paripurna yang menyediakan pelayanan rawat inap, rawat jalan, dan gawat darurat (Indonesia, 2009). Rumah sakit memiliki berbagai bentuk pelayanan, salah satunya yaitu pelayanan rawat jalan. Rawat jalan adalah pelayanan medis kepada seorang pasien dan tidak lebih dari 24 jam pelayanan untuk tujuan pengamatan, diagnosis, pengobatan, rehabilitasi, dan pelayanan kesehatan lainnya, tanpa mengharuskan pasien tersebut di rawat inap (Ismawati, Yulianti, \& Sari, 2021).

Upaya untuk meningkatkan pelayanan yang dilakukan oleh Rumah Sakit adalah dengan menyelenggarakan berbagai unit sebagai pelakasana program-program untuk tercapainya pelayanan berkualitas. Salah satu indikator pelayanan yang berkualitas adalah dengan tercapainya tertib administrasi yang dapat dilihat dari sistem pengelolaan rekam medis yang baik. Rumah sakit membutuhkan unit-unit pembantu untuk menjalankan tugasnya, diantaranya adalah unit rekam medis (Budi, 2011).

Rumah Sakit Dustira merupakan salah satu Rumah Sakit rujukan COVID-19. Berdasarkan penelitian banyaknya pasien COVID-19 yang dirujuk ke Rumah Sakit Dustira sehingga jumlah pengunjung pasien rawat jalan di Rumah Sakit Dustira setelah menjadi Rumah Sakit rujukan COVID-19 mengalami penurunan. Pada tahun 2018 jumlah pengunjung ada 349.117 pasien, tahun 2019 ada 295.680 dan pada tahun 2020 ada 188.307 pasien. Urgensi penelitian ini adalah penulis ingin menganalisis minat pasien berobat terhadap rumah sakit yang menjadi rujukan COVID-19. Berdasarkan hal-hal serta fakta di 
atas maka penulis melakukan penelitian dengan judul Analisis Pengunjung Pasien Rawat Jalan di Rumah Sakit Dustira Pre And Post Sebagai Rumah Sakit Rujukan COVID-19.

\section{METODE PENELITIAN}

Penelitian ini menggunakan metode kuantitatif dan dengan pendekatan deskriptif. Dimana penelitian kuantitatif jenis penelitian yang dapat dicapai (diperoleh) dengan menggunakan prosedur-prosedur secara statistik atau cara lainnya dari suatu kuantifikasi (pengukuran). Teknik pengumpulan data dalam penelitian ini melalui sumber data primer dan data sekunder. Sumber data primer didapatkan penulis langsung dari objek penelitian yang diteliti dengan cara wawancara dan observasi. Pada sumber data sekunder, penulis mengumpulkan data dengan cara melalui Teknik pengumpulan data menggunakan wawancara (interview), pengamatan (observasi), studi pustaka (Timotius, 2017).

Populasi pada penelitian ini populasinya yakni data pengunjung pasien rawat jalan. Sampel yang diambil pada penelitian ini adalah jumlah pengunjung pasien rawat jalan dari triwulan pertama tahun 2018 sampai triwulan pertama tahun 2021. Teknik yang digunakan yaitu teknik simple random sampling. Hipotesis yang akan di uji dalam penelitian ini adalah ada atau tidaknya pengaruh sigmifikan dari Rumah Sakit Dustira sebagai Rumah Sakit rujukan COVID-19 terhadap jumlah pengunjung pasien rawat jalan, jika tidak terdapat pengaruh yang signifikan maka diformulasikan dalam hipotesis Nol (H0) untuk ditolak. Tetapi apabila ternyata ada pengarus yang signifikan apabila kedua variabel dihipotesiskan, maka diformulasikan dalam hipotesis alternative (H1), yaitu hipotesis yang diharapkan untuk diterima.

\section{HASIL DAN PEMBAHASAN}

\section{A. Hasil Penelitian}

Penelitian mengenai analisis pengunjung pasien rawat jalan di Rumah Sakit Dustira pre and post sebagai Rumah Sakit rujukan COVID-19. Diperoleh hasil sebagai berikut.

Adapun data dan informasi dari hasil observasi dan wawancara yang penulis dapatkan dari staff rekam medis dan INFOKES di Rumah Sakit Dustira :

a. Penurunan jumlah pengunjung pasien rawat jalan disebabkan karena Rumah Sakit Dustira itu sebagai Rumah Sakit rujukan dan kebijakan sistem regional yang di terapkan oleh BPJS.

\begin{tabular}{lc}
\hline \multicolumn{1}{c}{ Data } & Jumlah Pengunjung Pasien Rawat Jalan \\
\hline Trw 1 tahun 2018 & 97.065 \\
\hline Trw 2 tahun 2018 & 88.990 \\
\hline Trw 3 tahun 2018 & 91.891 \\
\hline Trw 4 tahun 2018 & 71.180 \\
\hline Total pengunjung tahun 2018 & 349.117 \\
\hline Trw 1 tahun 2019 & 76.874 \\
\hline Trw 2 tahun 2019 & 69.531 \\
\hline Trw 3 tahun 2019 & 74.702 \\
\hline Trw 4 tahun 2019 & 74.573 \\
\hline Total pengunjung tahun 2018 & 295.680 \\
\hline Trw 1 tahun 2020 & 71.991 \\
\hline
\end{tabular}

Analisis Pengunjung Pasien Rawat Jalan di Rumah Sakit Dustira Pre and Post Sebagai Rumah Sakit Rujukan COVID-19 


\begin{tabular}{lc}
\hline Trw 2 tahun 2020 & 32.605 \\
\hline Trw 3 tahun 2020 & 44.536 \\
\hline Trw 4 tahun 2020 & 39.175 \\
\hline Total pengunjung tahun 2020 & 188.307 \\
\hline Trw 1 tahun 2021 & 38.900 \\
\hline
\end{tabular}

b. Berdasarkan tabel $1 \mathrm{di}$ atas merupakan data jumlah pengunjung rawat jalan dari triwulan pertama tahun 2018 sampai triwulan pertama tahun 2021.

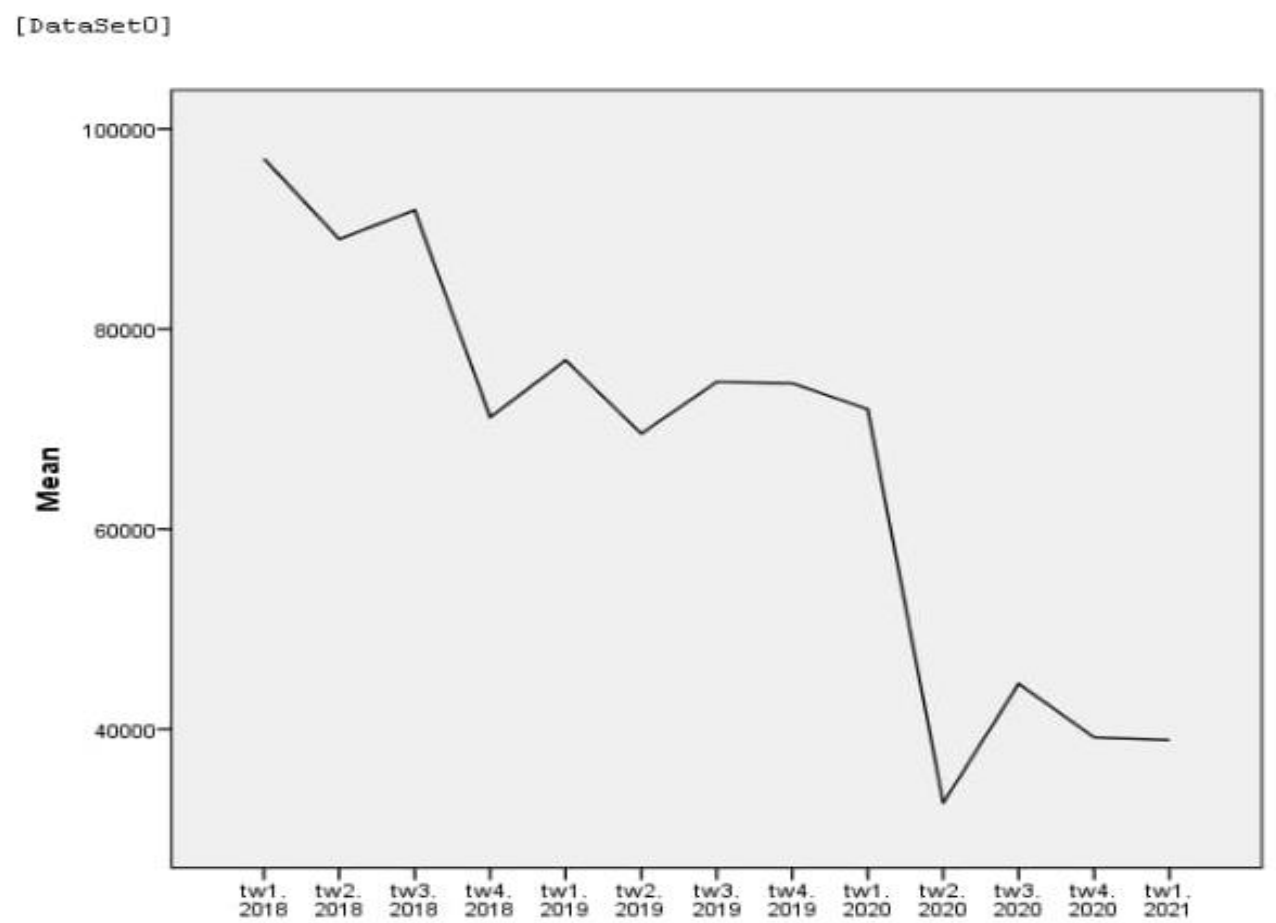

Gambar 1. Grafik Hasil Statistik Deskriptif

\section{B. Pembahasan}

Dari grafik hasil penelitian analisis pengunjung pasien rawat jalan rumah sakit Dustira pre and post sebagai rumah sakit rujukan COVID-19, menunjukan bahwa penurunan pengunjung pasien rawat jalan bukan akibat dari rumah sakit Dustira sebagai rumah sakit rujukan COVID-19. Namun ada faktor eksternal atau faktor lain yang menjadikan pengunjung pasien rawat jalan salah satunya yaitu kebijakan regional BPJS Kesehatan, yang mana pasien tidak diperkenankan untuk langsung mengunjungi fasilitas pelayanan yang diinginkan tetapi pasien harus terlebih dahulu mengunjungi fasyankes tingkat 1/pratama. Karena rumah sakit Dustira tergolong rumah sakit tingkat 3 maka dari itu alur pelayanan pasien yang menjadikan rumah sakit Dustira mengalami penurunan pengunjung pasien rawat jalan.

\section{KESIMPULAN}

Sebagaimana penelitian di atas disimpulkan tentang Analisis Pengunjung Pasien Rawat Jalan di Rumah Sakit Dustira Pre and post Sebagai Rumah Sakit Rujukan COVID19, yakni H0 diterima dan H1 ditolak yang dapat diterjemahkan bahwa sebagai Rumah Analisis Pengunjung Pasien Rawat Jalan di Rumah Sakit Dustira Pre and Post Sebagai Rumah Sakit Rujukan COVID-19 
Sakit rujukan COVID-19 tidak menjadikan Rumah Sakit Dustira mengalami penurunan jumlah pengunjung pasien rawat jalan. Karena hasil dari grafik sudah menunjukan penurunan dari tahun 2018 sementara COVID-19 terjadi di tahun 2020 bulan maret. Selain itu dalam sesi wawancara penulis menemukan jawaban bahwa kebijakan sistem regional BPJS lah yang menjadi alasan Rumah Sakit Dustira mengalami penurunan jumlah pengunjung pasien rawat jalan.

\section{BIBLIOGRAFI}

Budi, Savitri Citra. (2011). Manajemen unit kerja rekam medis. Yogyakarta: Quantum Sinergis Media.

HK, Kepmenkes R. I. Nomor. (2020). 01.07. Menkes/169/2020 Concerning the Establishment of a Reference Hospital for the Prevention of Certain Emerging Infection Diseases.

Indonesia, P. R. (2009). Undang-Undang Republik Indonesia Nomor 44 Tahun 2009 Tentang Rumah Sakit.

Ismawati, Indri, Yulianti, Nurul Aulia, \& Sari, Irda. (2021). Faktor-Faktor Penyebab Keterlambatan Distribusi Rekam Medis Rawat Jalan di Rumah Sakit TK II Dustira Cimahi. Cerdika: Jurnal Ilmiah Indonesia, 1(7), 8015-8020.

Launa, Launa. (2020). Banjir Infodemi: Viralitas Akurasi Berita Virologi Dalam Fenomena Coronavirus Disease. The Source: Jurnal Ilmu Komunikasi, 2(2), 1-21.

Lukman, Wahyuddin, \& Malik, D. A. (2020). COVID-19: Tinjauan Sejarah Virus Dunia \& Kebijakan Hukum Penanganan COVID-19 di Indonesia. GUEPEDIA.

Megakartikaningtyas, Elina. (2021). Tingkat pengetahuan dan perilaku penggunaan kunyit (Curcuma longa Linn.) pada masyarakat di Desa Beran Kabupaten Ngawi saat Covid-19. Universitas Islam Negeri Maulana Malik Ibrahim.

Nabila, Thasya. (2021). Skripsi Literature Review: Hipertensi Sebagai Komorbid Pada Pasien COVID-19.

Oktaviani, Hani. (2021). Perlindungan Hukum Terhadap Tenaga Kesehatan Atas Kurangnya Alat Pelindung Diri (APD) Dalam Tindakan Penanganan Pasien COVID-19 di Rumah Sakit" X" dikaitkan Dengan Undang-Undang Nomor 36 Tahun 2009 Tentang Kesehatan. Fakultas Hukum Uiversitas Pasundan.

Timotius, Kris H. (2017). Pengantar Metodologi Penelitian: Pendekatan Manajemen Pengetahuan untuk Perkembangan Pengetahuan. Penerbit Andi.

Wulandari, Rizky. (2021). Analisis Implementasi Kebijakan Politik Pemerintah Indonesia dalam Mengantisipasi Sampah Plastik. Fakultas Ilmu Sosial dan Ilmu Politik.

(C) 2021 by the authors. Submitted for possible open access publication under the 